Wang, C., Brabenec, T., Gao, P., \& Tang, Z. (2021). The Business Strategy, Competitive Advantage and Financial Strategy: A Perspective from Corporate Maturity Mismatched Investment. Journal of Competitiveness, 13(1), 164-181. https://doi.org/10.7441/joc.2021.01.10

\title{
The Business Strategy, Competitive Advantage and Financial Strategy: A Perspective from Corporate Maturity Mismatched Investment
}

\author{
- Can Wang, Tomas Brabenec, Peng Gao, Ziyu Tang
}

\begin{abstract}
Competitive advantage is the key to a company's success, and the business strategy represents a long-term plan to achieve a competitive advantage by affecting the company's financial behavior. This research studies the interaction of business strategy, competitive advantage, and financial strategy to explore whether companies choose different financial strategies based on their business strategies as well as what role competitive advantage plays in their decision-making. By building a composite index and observing maturity mismatched investment, this research quantifies the risk level of business strategies and financial strategies. Using text analysis of a company's annual report, the research builds a dummy variable to measure the competitive advantage. Based on the samples of A-shares listed on the China Shanghai and Shenzhen stock exchanges from 2007 to 2016, the research shows that the risk level of business strategy and financial strategy tends to move in opposite directions. If a company embraces an aggressive business strategy, it is more likely to choose a conservative financial approach in terms of lower overall risks, but for the company with a competitive advantage, the negative correlation between these two strategies is weakened. Further analysis found that company ownership, free cash flow, and the quality of internal control also play a significant role in the interaction between business strategy and financial strategy. Our findings not only enrich research on business strategy and financial behavior, but also deepen the understanding of competitive advantage and corporate financial strategy theoretically.
\end{abstract}

Keywords: business strategy, competitive advantage, corporate financial strategy, financial risk, maturity mismatch

JEL Classification: G30, G31, G32

Received: September, 2020

1st Revision: January, 2021

Accepted: January, 2021

\section{INTRODUCTION}

Achieving a competitive advantage to survive in an increasingly competitive market environment is always a prime target for theoretical research as well as practical strategy conception. As business strategy determines the long-term path and goals of companies, it can also help to 
achieve competitive advantage in various ways. Established academic strategic research categorizes business strategy into three types of actor based on the level of aggression: defenders, analyzers, and prospectors (Miles et al., 1978). Prospectors focus on developing new products and markets to gain competitive advantage; defenders focus on existing market and achieve competitive advantage by ensuring the best price and service; while analyzers function in ways in between that of prospectors and defenders. As business strategies determine the behavior of companies to achieve a competitive advantage, they also provide companies with different characters in terms of financial activity. For instance, previous research quantificationally measuring business strategy by corporate accounting data has found that when a company implements the prospectors approach, financial fraud is more likely to ensue (Bentley et al., 2013).

Previous research on the impact of business strategy on financial behavior has mainly focused on the perspective of information disclosure and agency issues. Less discussion has taken place on corporate financial strategy, although this represents an essential part of working capital management. A good financial approach improves corporate profitability and asset security (Gao \& Liu, 2012). Previous works of literature have claimed that corporate financial strategies can be divided into three types based on the level of maturity mismatched investment, namely an aggressive strategy, a prudent strategy, and a conservative strategy (Gao \& Liu, 2012; Zhong et al., 2016). Among these approaches, a corporate aggressive financial strategy describes a company willing to take maturity mismatch risks to secure investment opportunities. As the prospector considers innovation as their primary source of competitive advantage, it is reasonable to believe that compared with defenders, prospectors are less willing to submit to the supervision of the creditors. In addition, prospectors will choose to face a higher risk of investment failure and poor performance as they seek better growth and higher valuation (Miles et al., 1978; Wang et al., 2018). Therefore, prospectors have not only the motivation to avoid applying an aggressive financial strategy, but also have the capability to raise funds from other channels such as equity financing. It is then reasonable to assume that, compared with defenders, prospectors may engage in less maturity mismatched investment. Moreover, as the business strategy determines the path to achieve a competitive advantage, companies may change their financial behaviors to make better use of their own benefits. It is thus plausible that competitive advantage could influence the relationship between the business strategy and financial behavior.

This paper takes Shanghai and Shenzhen A-share listed companies from 2007 to 2016 as samples. By applying accounting data to measure business strategy (Bentley et al., 2013) using textual data to measure competitive advantage, this paper empirically tests whether business strategy affects corporate financial strategy as represented by maturity mismatched investment, and whether competitive advantages change the relationships between them. In China, the financial system led by state-owned banks makes the investment mismatch problem of China's listed companies more obvious. China is not only the second-largest economy in the world, but also the largest developing country. The Chinese system can therefore serve as an telling comparison for other developing countries in the research of national competitiveness (Kowalski, 2020).

The remainder of the paper is organized as follows: the second section describes a theoretical background; the third reports the research objective, methodology and data; the fourth part communicates results and a discussion, and the fifth reports the conclusion. 


\section{THEORETICAL BACKGROUND}

Achieving a competitive advantage in the current competitive market situation is always a prime target of research. A business strategy determines a company's long-term goals and the methods to achieve them (Chandler, 1990). An appropriate business strategy can significantly improve the competitiveness of a company (Dvorský et al., 2020). Traditional academic strategic research categorizes business strategy into three types based on the level of aggression of the actors involved: defenders, analyzers, and prospectors (Miles et al., 1978). The prospectors focus on developing new products and markets to gain a competitive advantage; defenders focus on existing markets and achieve competitive advantage by ensuring the best price and service; while analyzers work with a strategy between that of prospectors and defenders. Within this framework, scholars have found that the business strategy is an essential factor in determining financial behavior. When a company implements a prospector strategy, it is more likely to experience financial fraud (Bentley et al., 2013). The following research has determined that in financial and other sectors, fraudulent behavior is more likely to experienced when the company embraces a prospector strategy (Meng et al., 2018).

Moreover, research has confirmed that from the perspective of accounting quality, companies with a prospector strategy engage in more earnings management behaviors (Sun et al., 2016), show lower accounting reliability (Liu, 2016), and produce lower quality annual reports (Lim et al., 2018). From the perspective of agency issues, managers have more motivation to benefit themselves by excessive investment (Wang et al., 2016) and perks (Wang et al., 2019), but pay employees less (Sheng et al., 2019; Wu et al., 2018). This strategy also produces serious information asymmetry problems as well as provides managers more motivation to make secret deals (Chen $\&$ Keung, 2019). Although the prospector strategy is more attractive for stock analysts, it lowers predictive accuracy (Ding \& Chen, 2020). The most recent research has demonstrated that the corporate strategy can also influence corporate environmental policies. Firms following prospector strategies take more putative environmental protection actions, but engage in less sustainable development behaviors (Kong et al., 2020; Liu \& Kong, 2020).

The previous literature has produced much discussion on the impact of business strategy on financial behavior, but mainly regarding information disclosure and agency problems. Less discussion on the topic of corporate financial strategy has come forth. As a kind of aggressive financial behavior, maturity mismatched investment has a significant negative impact on a company's performance (Zhong et al., 2016). As compared with other countries, in China short-term debt has become the main debt financing channel, due to the severe information asymmetry and creditor protection problems they have faced (Sorge et al., 2017). Therefore, it is of great practical significance to study the influence of business strategy on maturity mismatched investment. Moreover, since the business strategy represents a long-term plan to achieve a competitive advantage, the condition of competitive advantage might also have an impact on corporate behavior. Incorporating competitive advantage into the analysis can deepen the understanding of the business strategy and financial behavior.

Different business strategies employ various methods to achieve a competitive advantage. Several reasons exist for prospectors to have a stronger motivation to apply relatively conservative financial strategies. First of all, considering the fact that creditors only obtain a fixed income but must bear 
all the risks of corporate investment failure, the behavior of companies in terms of continuing with high-risk investment may not meet creditor interests. This leads to the tendency of financial institution to demand higher returns when providing loans to innovative companies (Cowling et al., 2018). The existing literature has demonstrated that corporate debt financing can restrain innovation investment (Chen et al., 2016; Chiao, 2002). This is the case mainly when companies rely more on short-term debt for funding, at which time creditors can implement more strict supervision on corporate investment projects through demands for the repayment of the principal or interest, and they can demand more frequent credit contract negotiations (Jensen \& Meckling, 1976; Zhong et al., 2016). Innovation is the main competitive advantage of prospectors (Miles et al., 1978). Therefore, to avoid the adverse effects of short-term debt on innovation, prospectors have the motivation to obtain investment funds through other financing channels. Secondly, compared with defenders, prospectors emphasize more on developing new products, expand to new markets, and have higher R\&D expenditure, thus facing a higher risk of investment failure, higher output uncertainty, and a higher risk of poor performance (Miles et al., 1978). In this condition, if the prospectors rely more on short-term debt to finance investment and adopt more aggressive financial strategies, it will lead to a further increase of corporate risk (Rehman, 2017; Zhong et al., 2016). Furthermore, if corporate innovation fails and performance declines, the aggressive financial strategy will even lead to debt default, which seriously damages corporate value. To sum up, prospectors have a stronger incentive to raise funds other than short-term debt and adopt more conservative financial strategies to avoid the maturity mismatch risk.

Moreover, prospectors have a stronger ability to use more conservative financial strategies. Firstly, compared with defenders, prospectors have a stronger ability to obtain equity financing because they have a better growth rate than the defenders (Miles et al., 1978). Considering the venture capital who pursue high risk and high return prefer to invest those companies with high growth (Long \& Chang, 2008), the prospectors are more comfortable to obtain the investment from them. On the other side, the existing works of literature support that prospectors generally have higher valuation (Wang et al., 2018), so they can raise funds from the equity market at a lower cost. In fact, in China and worldwide, compared with the credit market, the equity market can provide more financial support for corporate innovation (Brown et al., 2013; Xia $\& \mathrm{Lu}, 2012)$. Secondly, compared with defenders, prospectors have a stronger ability to obtain government support which plays a vital role in promoting companies' innovation (Filipová et al., 2016). In China, government financial subsidies and tax incentives are crucial external financing channels to support R\&D investment by companies (Wang, 2011). The Chinese government has always attached great importance to innovation. It has issued a series of policies to support the development of innovative companies, including preferential tax policies and land policies. The government's support policies will help ease the financing constraints of prospectors and reduce their dependence on short-term debt. Finally, scholars have confirmed that prospectors have more substantial bargaining power and marginal profit in the product market because of the advantage from new products and new markets. Compared with defenders, prospectors have stronger profitability (Wang et al., 2018). The prospectors have stronger internal financing ability and less dependence on short-term debt. Therefore, it is reasonable to believe that prospectors are in a better position to raise fund from other than short-term debt channel, and likely to adopt more conservative financial strategies to avoid maturity mismatch risk. 
To summarize, this paper believes that business strategy has a significant impact on corporate financial strategy, and therefore, this paper puts forward Hypothesis 1:

H1: Compared with defenders, prospectors will adopt more conservative financial strategies, and maturity mismatched investment will relatively lower.

This research believes that business strategy reflects the path for companies to gain competitive advantage. Prospectors gain competitive advantages through innovation, while defenders gain competitive advantage by improving operating efficiency (Miles et al., 1978). If the goal of business strategies is to achieve a competitive advantage, then the current condition of competitive advantage might also have an impact on the relationship between business strategies and financial behavior.

There are two reasons for prospectors to try to avoid the use of short-term debt. First, the negative impact of short-term debt on innovation and the prospectors' capability to achieve competitive advantages (Chen et al., 2016; Chiao, 2002). Second, the volatility of prospectors' performance is more considerable, and the aggressive financing strategy might further increase the company's risk (Miles et al., 1978; Zhong et al., 2016). But when a company already got competitive advantages, the capability of risk-taking and innovation efficiency will increase (Wu, 2010). The negative impact of maturity mismatched investment on prospectors has been weakened. From the demand perspective, prospectors tend to be more reliant on financing, while the short-term debt has relatively low interest rates (Sun et al., 2016). Therefore, prospectors might prefer short-term financing options when it has competitive advantages. From the supply perspective, state-owned banks play a leading role in China's financial system. They are the major fund supplier for the company's business and economic growth (Ayyagari et al., 2010). To serve their own interests, banks prefer to provide short-term loans to those high-quality companies to reduce risks (Zhong et al., 2016), and prospectors with competitive advantages are easier to get short-term financing from banks. To summarize, this research believes the competitive advantage could weaken the negative correlation between business strategy and mismatched investment. Therefore, this research proposes the following assumptions:

H2: The prospectors' strategy will have a less negative impact on maturity mismatched investment behavior when the company has a competitive advantage.

\section{RESEARCH OBJECTIVE, METHODOLOGY AND DATA}

This paper uses Shanghai and Shenzhen A-share listed company samples from 2007 to 2016 for empirical research. After excluding the companies from the financial industry, companies listed less than five years, and missing variables, this paper finally gets a company-year sample of 15,203 observations from 2007 to 2016. The data used in this paper are from the database of China Stock Market \& Accounting Research Database (CSMAR), Wind Database (WIND), and Chinese Research Data Services Platform (CNRDS). To adjust the influence from extreme value, this paper has minorized all continuous variables at the level of $1 \%$ and $99 \%$.

Business strategy is divided into three types: prospectors, analyzers, and defenders based on the business strategy's degree of aggression (Miles et al., 1978). Referring to the previous research 
(Bentley et al., 2013), this research first constructs business strategy variables. As shown in Table 1 , each variable mainly focuses on six corporate dimensions. Then divide each variable into five groups from small to large and assign them a value. For the first five variables, the minimum group is assigned as 1 , the second group is assigned as 2 , the setting of the other group is the same until the maximum group is assigned as 5 ; while the sixth variable is opposite, the minimum group is assigned as 5, the next group is assigned as 4 , until the maximum group is assigned as 1 .

Finally, this research builds a company strategy aggressive score by adding the assigned value of those six variables. The range of this score is from 6 to 30. The higher the strategic score is, the more aggressive the corporate business strategy is.

Tab. 1 - The characteristics and measurement of business strategy. Source: own research

\begin{tabular}{|c|c|c|}
\hline $\begin{array}{l}\text { Dimensions of Strategic } \\
\text { Characteristics }\end{array}$ & Specific Performance & Measurement Method \\
\hline $\begin{array}{l}\text { Whether to pay attention } \\
\text { to the development of new } \\
\text { products }\end{array}$ & $\begin{array}{l}\text { Compared with defenders, } \\
\text { prospectors pay more } \\
\text { attention to innovation } \\
\text { behavior and innovation } \\
\text { expenditure. }\end{array}$ & $\begin{array}{l}\text { The proportion of R\&D } \\
\text { expenditure in sales revenue, } \\
\text { based on moving average } \\
\text { over the past five years. }\end{array}$ \\
\hline $\begin{array}{l}\text { Whether to pay attention to } \\
\text { corporate business efficiency }\end{array}$ & $\begin{array}{l}\text { Compared with defenders, } \\
\text { prospectors pay less attention } \\
\text { to business efficiency and } \\
\text { the individual ability of their } \\
\text { employees to generate income } \\
\text { is weak. }\end{array}$ & $\begin{array}{l}\text { This paper uses the number } \\
\text { of employees divided by sales } \\
\text { revenue to measure it, and } \\
\text { it is adjusted by the moving } \\
\text { average of the past five years. }\end{array}$ \\
\hline Corporate growth & $\begin{array}{l}\text { Compared with defenders, } \\
\text { prospectors usually have } \\
\text { better growth. }\end{array}$ & $\begin{array}{l}\text { One-year percentage change } \\
\text { in total sales adjusted by the } \\
\text { moving average of the past } \\
\text { five years. }\end{array}$ \\
\hline $\begin{array}{l}\text { Whether to pay attention to } \\
\text { product-market expansion }\end{array}$ & $\begin{array}{l}\text { Compared with defenders, } \\
\text { prospectors pay more } \\
\text { attention to product-market } \\
\text { expansion and have higher } \\
\text { sales and management costs. }\end{array}$ & $\begin{array}{l}\text { Ratio of selling, general and } \\
\text { administrative expenses to } \\
\text { sales based on the moving } \\
\text { average of the past five years. }\end{array}$ \\
\hline $\begin{array}{l}\text { Whether the organization is } \\
\text { stable }\end{array}$ & $\begin{array}{l}\text { Compared with the } \\
\text { defenders, the organizational } \\
\text { stability of the prospectors is } \\
\text { relatively weak, which mainly } \\
\text { reflects in the relatively short } \\
\text { tenure of employees. }\end{array}$ & $\begin{array}{l}\text { Standard deviation of the } \\
\text { total number ofemployees } \\
\text { computed over moving } \\
\text { average over the past five } \\
\text { years. }\end{array}$ \\
\hline
\end{tabular}




\begin{tabular}{|l|l|l|}
\hline $\begin{array}{l}\text { Whether to pay attention to } \\
\text { human capital }\end{array}$ & $\begin{array}{l}\text { Prospectors usually pay more } \\
\text { attention to human capital } \\
\text { investment, while defenders } \\
\text { usually pay more attention to } \\
\text { fixed-asset investment. }\end{array}$ & $\begin{array}{l}\text { Calculated by net PPE } \\
\text { divided by total assets based } \\
\text { on the moving average of the } \\
\text { past five years. }\end{array}$ \\
\hline
\end{tabular}

Referring to the previous research (Zhong et al., 2016), maturity mismatched investment (MMI) is defined as follows:

Maturity Mismatched Investment $=$ Cash Outflow from Construction of Fixed Assets and Other Investment Activities - Increase of Long-term Loan in the Current Period - Increase of Equity in the Current Period - Net Cash Flow from Operating Activities - Cash Inflow from Disposal of Fixed Assets and Other Cash Inflows.

And the Increase of Long-term Loan in the Current Period is calculated by:

Increase of Long-term Loan in the Current Period = Long-term Loan in the Current Period Long-term Loan in the Last Period + Non-current Liabilities Due within One Year.

At last, this research uses the total assets of the last period to eliminate the scale effect.

Competitive advantage reflects the advantages of companies over competitors in internal operating efficiency and external market efficiency, including the speed of response to the market, production efficiency, product quality, and innovation speed (Wu, 2010). Whether at the firm or national level, measuring the competitive advantage has always been a valuable topic (Ruzekova et al., 2020). The previous research on company competitiveness was limited by data sources, and a questionnaire survey was the most common measurement method. As the research sample is based on A-share listed companies from 2007 to 2016, it is difficult to directly observe the competitive advantage by questionnaire. Therefore, this research uses text analysis on the "Management Discussion and Analysis" (MD\&A) of the annual reports of observed companies to defining the company's competitive advantage.

Managers have discretion in writing annual reports (Merkl-Davies \& Brennan, 2007), when managers disclose yearly report information, there is no financial incentive to guide them to report opportunistic events. Therefore, managers will objectively use written discretion to convey information about the company's operating conditions. (Clarkson et al., 2013). Related researches use text analysis to study companies' annual reports. Through text analysis of MD\&A, the research found that the more factors mentioned in the annual reports that have a negative impact on performance, the less likely it is to turn losses, and the more strategic improvement measures mentioned in the business plan, the greater the possibility of turning losses in the next year (Xue et al., 2010). Besides, the China Securities Regulatory Commission has issued a series of policies in recent years to restrict the accuracy of company annual report disclosure. Therefore, this research believes using text analysis on MD\&A of the yearly reports of observed companies can accurately and sufficiently define its competitive advantage.

This research uses the annual reports disclosed MD\&A from the CNRDS database, and then identifies the relative words of competitive advantage from Tencent AI Lab Embedding Corpus for Chinese Words and Phrases by Natural Language Processing (NLP) method. At the final 
step, identify whether the existence of competitive advantage relative words in MD\&A. This research uses a dummy variable to represent the competitive advantage. If the test identified relative terms in textual data, then the competition value will be set as 1 . Otherwise, it is 0 .

Following the previous research, this paper selects the controlled variables from the companies' essential characteristics and their corporate governance (Sun et al., 2016; Wang et al., 2016). The essential characteristics of companies include corporate size, leverage, and profitability. The characteristics of corporate governance include the proportion of the largest shareholder, the board size, the board of directors' shareholding, the proportion of independent directors, and shares held by institutional investors. Finally, this paper uses the year and industry dummy variables to control the fixed effects of time and industry. The variables and measurement of variables can be seen in Table 2 .

Tab. 2 - Variable definition. Source: own research

\begin{tabular}{|l|l|l|}
\hline \multirow{4}{*}{$\begin{array}{l}\text { Dependent } \\
\text { Variable }\end{array}$} & Variable & Explanation \\
\hline $\begin{array}{l}\text { Independent } \\
\text { Variable }\end{array}$ & Strategy & $\begin{array}{l}\text { As described above, it refers to the previous research } \\
\text { (Zhong et al., 2016). }\end{array}$ \\
\cline { 2 - 3 } & Competitive & $\begin{array}{l}\text { As described above, it refers to the research of Bentley et } \\
\text { al. to construct discrete variables (Bentley et al., 2013). }\end{array}$ \\
\hline \multirow{4}{*}{$\begin{array}{l}\text { Controlled } \\
\text { variables } \\
(\text { CV })\end{array}$} & Size & MD\&fined by using text analysis on their annual reports' \\
\cline { 2 - 3 } & Lev & Natural logarithm of total assets \\
\cline { 2 - 3 } & Roe & Total liabilities/Total assets \\
\cline { 2 - 3 } & First & Rate of Return on Common Stockholders' Equity \\
\cline { 2 - 3 } & Board & The proportion of the largest shareholder \\
\cline { 2 - 3 } & Boardstock & The proportion of board of directors' shareholding \\
\cline { 2 - 3 } & Ind & Independent directors/Number of board directors \\
\cline { 2 - 3 } & Institution & The proportion of shares held by institutional capitalists \\
\hline
\end{tabular}

To test Hypothesis 1, this paper constructs the regression model 1 to test whether the business strategy impacts maturity mismatched investment (Sun et al., 2016; Wang et al., 2016). The definition of variables in model 1 is shown in Table 2. If Hypothesis 1 is correct, the business strategy should negatively relate to mismatched investment, and $\beta_{1}$ should be significantly negative.

MMI $_{i, t}=\beta_{0}+\beta_{1}$ Strategy $_{i, t}+\beta_{2}$ Size $_{i, t}+\beta_{3} \operatorname{Lev}_{\mathrm{i}, \mathrm{t}}+\beta_{4}$ Roe $_{\mathrm{i}, \mathrm{t}}+\beta_{5}$ First $_{\mathrm{i}, \mathrm{t}}+\beta_{6}$ Board $_{\mathrm{i}, \mathrm{t}}+\beta_{7}$ Boardstock $_{\mathrm{i}, \mathrm{t}}+\beta_{8}$ Ind $_{\mathrm{i}, \mathrm{t}}+\beta_{9}$ Insititution $_{\mathrm{i}, \mathrm{t}}+$ Industry + Year $+\varepsilon$

To test Hypothesis 2, the research groups the data by the value of the competitive dummy variable and regress two groups separately. If Hypothesis 2 is true, then the $\beta_{1}$ should be larger in the competitive advantage group. 


\section{RESULTS AND DISCUSSION}

Table 3 reports the statistical analysis of the main variables in this paper. The average value of maturity mismatched investment (MMI) is -0.166 , and the median is -0.076 , indicating that fewer companies face maturity mismatched investment issues. The standard deviation is 0.463 , indicating significant differences in mismatched investment behaviors among different companies. The average value of the business strategy is 18.029 , the median is 18.000 , and the standard deviation is 4.007, which indicates some differences among different types of strategies. The average value of competitive is 0.738 , the median is 1.000 , and the standard deviation is 0.440 , which indicates that most listed companies disclose their competitive advantages in their annual reports. Other variables in this paper are not described in detail here.

Tab. 3 - Descriptive statistics of main variables. Source: own research

\begin{tabular}{|l|l|l|l|l|l|l|}
\hline Variables & No of Samples & Mean & Median & St. Dev. & Min. & Max. \\
\hline MMI & 15203 & -0.166 & -0.076 & 0.463 & -3.699 & 0.335 \\
\hline Strategy & 15203 & 18.029 & 18.000 & 4.007 & 6.000 & 30.000 \\
\hline Competitive & 15203 & 0.738 & 1.000 & 0.440 & 0.000 & 1.000 \\
\hline Size & 15203 & 22.043 & 21.940 & 1.317 & 18.684 & 25.810 \\
\hline Lev & 15203 & 0.502 & 0.497 & 0.232 & 0.069 & 1.492 \\
\hline Roe & 15203 & 0.058 & 0.063 & 0.185 & -1.070 & 0.837 \\
\hline First & 15203 & 34.324 & 32.000 & 15.151 & 8.340 & 74.960 \\
\hline Board & 15203 & 8.903 & 9.000 & 1.825 & 3.000 & 18.000 \\
\hline Boardstock & 15203 & 0.051 & 0.000 & 0.123 & 0.000 & 0.550 \\
\hline Ind & 15203 & 0.370 & 0.333 & 0.052 & 0.300 & 0.571 \\
\hline Institution & 15203 & 38.971 & 39.480 & 23.152 & 0.000 & 87.380 \\
\hline
\end{tabular}

According to the type of business strategy, this research divides the samples into prospectors, non-prospectors, defenders, and non-defenders, then tests the mismatch investment difference in groups. Table 4 reports the statistical results, and it is shown that the average and median of mismatched investment in prospectors are lower than that in non-prospectors, and the difference between them is significant at the level of $1 \%$; the average and median of mismatched investment in defenders are higher than that in non-defenders, and the difference between them is significant at the level of $1 \%$. This result suggests that business strategy has a significant impact on the maturity mismatched investment. The more aggressive the business strategy is, the less mismatched investment the company has.

Tab. 4 - Single-variable Test. Source: own research

\begin{tabular}{|l|l|l|l|l|l|l|l|}
\hline & Mean & Median & & Mean & Median & T test & Z test \\
\hline Prospectors & -0.343 & -0.102 & $\begin{array}{l}\text { Non- } \\
\text { prospectors }\end{array}$ & -0.149 & -0.074 & $14.52^{* * *}$ & $8.37^{* * *}$ \\
\hline Defenders & -0.090 & -0.064 & Non-defenders & -0.173 & -0.078 & $-6.34 * * *$ & $-4.50 * * *$ \\
\hline
\end{tabular}

Note: $* * *$ indicates significance at $1 \%$ levels. $T$ test explains the significance of the mean difference. $Z$ test explains the importance of median difference. 
Table 5 reports the regression results of the model (1). To ensure the regression results are robust, this paper clustered the standard error of the regression coefficient at the corporate level. According to Table 5, without adding any controlled variables in regression (1), the business strategy coefficient is -0.016 , which is significantly negative at the $1 \%$ confidence level; in regression (2), after the control of industry and annual fixed effect, the business strategy coefficient is -0.016 , which is significantly negative at the $1 \%$ confidence level; in the regression (3), when the controlled variables, the fixed effects of industry and time are controlled at the same time, the coefficient of business strategy is -0.015 , which is significantly negative at the level of $1 \%$. The above results show that there is a significant negative correlation between business strategy and maturity mismatched investment behavior. The more aggressive the business strategy is, the less maturity mismatched investment behavior the company has. This result supports Hypothesis 1.

Tab. 5 - Business strategy and maturity mismatched investment. Source: own research

\begin{tabular}{|l|l|l|l|}
\hline \multirow{2}{*}{ Strategy } & $(1)$ & $(2)$ & $(3)$ \\
\cline { 2 - 4 } & $-0.016^{* * *}$ & $-0.016^{* * *}$ & $-0.015^{* * *}$ \\
\cline { 2 - 4 } CV & $(-13.60)$ & $(-13.66)$ & $(-12.73)$ \\
\hline Industry & NO & NO & YES \\
\hline Year & NO & YES & YES \\
\hline N & 15,203 & YES & YES \\
\hline Adj $\mathrm{R}^{2}$ & 0.0186 & 15,203 & 15,203 \\
\hline
\end{tabular}

Note: $* * *, * *, *$ indicate significance at $1 \%, 5 \%$ and $10 \%$ levels respectively. Adj $\mathrm{R}^{2}$ explains the variance explained by empirical model. Due to space limitations, the detailed regression results of the controlled variables $(\mathrm{CV})$ can be viewed by contacting the corresponding author, so are the following tables.

Table 6 reports the regression results of grouped samples. In the group without a competitive advantage, the coefficient of strategy is -0.018 and significant at $1 \%$ level. In the group with a competitive advantage, the coefficient of strategy is -0.013 and significant at $1 \%$ level. The seemingly unrelated regression (SUR) shows that the difference of coefficient between groups is significant at $10 \%$ level. These results suggest that prospectors' strategy will have a less negative impact on maturity mismatched investment behavior when the company has a competitive advantage, which consists of hypothesis 2 .

Tab. 6 - The influence of competitive advantages. Source: own research

\begin{tabular}{|l|l|l|}
\hline \multirow{2}{*}{ Strategy } & $\begin{array}{l}\text { Company without competitive } \\
\text { advantage (competitive=0) }\end{array}$ & $\begin{array}{l}\text { Company with competitive advantage } \\
(\text { competitive=1) }\end{array}$ \\
\cline { 2 - 3 } & $-0.018^{* * *}$ & $-0.013^{* * *}$ \\
\hline CV & $(-7.12)$ & $(-10.27)$ \\
\hline Industry & YES & YES \\
\hline
\end{tabular}




\begin{tabular}{|l|l|l|}
\hline Year & YES & YES \\
\hline $\mathrm{N}$ & 3,986 & 11,217 \\
\hline Adj $\mathrm{R}^{2}$ & 0.0502 & 0.0801 \\
\hline P-Value & 0.085 & \\
\hline
\end{tabular}

Note: $* * *, *$ indicate significance at $1 \%$ and $10 \%$ levels respectively. Adj $\mathrm{R}^{2}$ explains the variance explained by empirical model.

To make the conclusions of this study more robust, this research conducts robustness tests on the empirical results. Firstly, using dummy variables to measure business strategy and maturity mismatched investment (MMI) to control the impact of variable measurement methods. Secondly, using the fixed-effects model, PSM test, and HECKMAN test to control the influence of endogeneity on the conclusion. The empirical results of robustness tests show that the conclusions of this article are robust, and that aggressive business strategy significantly inhibits maturity mismatched investment behavior. However, due to space limitations, this article does not fully report the empirical results of the robustness test part. Interested readers can contact the corresponding author for detailed robustness test results.

Besides, to further understand the impact of business strategy on the behavior of maturity mismatched investment in different situations, this research selects three essential financial characteristics in Chinese companies which may influence the relationship between business strategy and maturity mismatched investment, including company ownership, free cash flow and internal control quality.

This research paper puts forth the claim that the ownership structure may influence the interaction between business strategy and financial strategy mainly through the following paths. First, compared with private companies, state-owned enterprises (SOEs) have more substantial risk-bearing capability. Considering that the actual controller of SOEs is the government, the firms are more likely to obtain help when faced with financial trouble. Secondly, the literature has confirmed that excellent corporate governance can reduce financial risk (Yu et al., 2008). Compared with private companies, it is evident that SOEs face relatively worse corporate governance due to agency problems (Liu et al., 2004). Thus, the SOEs may adopt a moderately aggressive financial strategy as well as engage in more maturity mismatched investment behaviors.

Based on the above analysis, this research divides the sample into a private company group and a state-owned company group. Most A-share listed companies in China have a dominant shareholder, thus the researchers can state the ownership of a company with certainty. Table 7 reports the grouped regression results of the model (1). The analysis shows that in the sample group of private companies, the business strategy coefficient is -0.016 , which is significant at the $1 \%$ level, whereas in the group of state-owned companies the coefficient of business strategy is -0.012 , which is significant at the $1 \%$ level. The seemingly unrelated regressions (SUR) test shows that the coefficient difference between groups is significant at the $10 \%$ level. This shows that compared with SOEs, the business strategy of private companies has a more negative effect on the mismatched investment.

Cash flow is an essential factor affecting corporate investment activities (Putintica \& Bonaci, 2013). When a corporation has sufficient free cash flow, its liquidity risk will decrease. Therefore, 
even companies using a prospector strategy are more likely to adopt aggressive financial strategies and have more mismatched investments. Based on the above analysis, firstly, corporate free cash flow is measured as:

The Adjusted Corporate Free Cash Flow $=$ Corporate Free Cash Flow $/$ Total Assets $=($ EBIT Taxation + Depreciation \& Amortization - Changes in Working Capital - Capital Expenditure)/ Total Assets.

The researchers divide a corporations' free cash flow by its total assets to control the scale effect, a method which makes free cash flow comparable between different companies.

Thus the sample is divided into a less corporate free cash flow group and a more corporate free cash flow group based on whether the corporate free cash flow is higher than the year-industry average. Table 7 reports the grouped regression results of the model (1). The analysis shows that in the group with less corporate free cash flow the coefficient of business strategy is -0.026 , which is significant at the level of $1 \%$; whereas in the group of more free cash flow the coefficient of business strategy is -0.007 , which is significant at the level of $1 \%$. The SUR test shows that the coefficient difference between groups is significant at the level of $1 \%$. This indicates that the prospector business strategy has a less negative effect on the mismatched investment in the samples of more corporate free cash flow.

Tab. 7 - The influence of ownership, free cash flow and internal control. Source: own research

\begin{tabular}{|l|l|l|l|l|l|l|}
\hline & $\begin{array}{l}\text { Private } \\
\text { Companies }\end{array}$ & $\begin{array}{l}\text { State- } \\
\text { Owned } \\
\text { Companies }\end{array}$ & $\begin{array}{l}\text { Less } \\
\text { Corporate } \\
\text { Free Cash } \\
\text { Flow }\end{array}$ & $\begin{array}{l}\text { More } \\
\text { Corporate } \\
\text { Free Cash } \\
\text { Flow }\end{array}$ & $\begin{array}{l}\text { Poor } \\
\text { Internal } \\
\text { Control } \\
\text { quality }\end{array}$ & $\begin{array}{l}\text { Good } \\
\text { Internal } \\
\text { Control } \\
\text { Quality }\end{array}$ \\
\hline Strategy & $-0.016^{* * *}$ & $-0.012^{* * *}$ & $-0.026^{* * *}$ & $-0.007 * * *$ & $-0.01 *^{* * *}$ & $-0.015^{* * *}$ \\
\hline & $(-8.56)$ & $(-9.26)$ & $(-10.82)$ & $(-6.75)$ & $(-6.60)$ & $(-9.81)$ \\
\hline CV & YES & YES & YES & YES & YES & YES \\
\hline In-dustry & YES & YES & YES & YES & YES & YES \\
\hline Year & YES & YES & YES & YES & YES & YES \\
\hline N & 6859 & 8344 & 5,299 & 9,904 & 6,413 & 8,122 \\
\hline Adj R2 & 0.0631 & 0.0763 & 0.112 & 0.062 & 0.072 & 0.074 \\
\hline P-Value & 0.054 & & 0.000 & & 0.084 & \\
\hline
\end{tabular}

Note: $* * *$ indicates significance at $1 \%$ levels. Adj $\mathrm{R}^{2}$ explains the variance explained by the empirical model.

Internal control is an essential part of risk management represented by the internal risk control mechanism of the organization (Ding \& Hu, 2007). Companies with reasonable internal control display a relatively higher capability of risk management. When applying the prospector business strategy, a company will devote more attention to the rising business risk of aggressive financial strategy; thus, the mismatched investment is reduced.

Following the analysis, this paper divides the sample into a low internal control group and an excellent internal control group based on whether the corporate internal control quality is higher than the year-industry average. The quality of corporate internal control is measured by the Dibo 
Internal Control Index. Table 7 reports the grouped regression results of the model (1). The analysis shows that in the group with a low quality of internal control the coefficient of business strategy is -0.011 , which is significant at the level of $1 \%$; whereas in the group with good quality of internal control the coefficient of business strategy is -0.015 , which is significant at the level of $1 \%$. The SUR test shows that the coefficient difference between groups is significant at the level of $10 \%$. This indicates that when the quality of internal control is good, the prospector strategy has a more substantial negative effect on mismatched investment.

This research complements the literature that examines the impact of business strategy on financial behaviors in the following ways.

First, this paper enriches the relevant literature in the cross-field of business strategy and financial strategy (Bentley et al., 2013; Sun et al., 2016). Other research studies have confirmed that business strategy has a significant impact on the investment behavior of listed companies (Wang et al., 2016). Nevertheless, only a few studies have focused on the impact of business strategy on financial strategy. From the perspective of maturity mismatched investment, this research finds that business strategy significantly impacts corporate maturity mismatched investment decisions. Moreover, in contrast to other researches which have found that prospectors tend to adopt negative financial behaviors, such as financial frauds (Bentley et al., 2013), show a lower quality of annual reports (Lim et al., 2018), as well as engage in more secret deals (Chen \& Keung, 2019), our results suggest that prospectors can choose the proper financial strategy according to their characters. There is a tradeoff between an aggressive business strategy and maturity mismatched investment. This finding can help companies better engage in effective risk management and governance to achieve a competitive advantage (Eccles et al., 2014; Rezaee, 2017). In addition, prospectors tend to take competitive advantage into consideration. This finding further supports the results that prospectors are more able to choose a proper financial strategy.

Second, in contrast to other studies which use questionnaires to measure competitive advantage (Wu, 2010), this research measures competitive advantage based on textual data from the annual reports of companies to use for empirical analysis, a strategy which has shown that competitive advantage has a significant impact on the relationship between a business strategy and financial behavior. This study thus enriches the literature on corporate competitive advantage.

Third, this paper enriches the relevant literature on corporate financial strategy. At present, scholars have conducted profound research on short-term debt financing behavior and investment behavior (Custódio et al., 2013; Hennessy, 2004; Huang et al., 2016; Kahl et al., 2015; Richardson, 2006), but few works of literature combine these two fields to study the maturity mismatch problem of long-term investment financed by short-term debt. With its basis on corporate financial data to measure corporate maturity mismatched investment behavior (Zhong et al., 2016), our paper has found that business strategy is a vital influence factor of corporate maturity mismatched investment decisions.

\section{CONCLUSION}

This paper shows the results of our study on the influence of business strategy on maturity mismatched investment based on the business strategy theory (Miles et al., 1978) and the strategy 
measurement method (Bentley et al., 2013). Compared with defenders, prospectors tend to achieve a competitive advantage by developing new products and exploring new markets. This strategy not only reduces the motivation of companies to use short-term financing but also puts them in a favorable position in other financing channels. This paper suggests that compared with defenders, the prospectors business strategy shows a tendency toward less maturity mismatched investment, and this conclusion is robust after control endogeneity issues. In the next test, this research brings data on competitive advantage into an empirical analysis framework, using textual data and a set of dummy variables to observe competitive advantage. This research groups the sample into two groups based on competitive dummy variables, regressing them separately. The results indicate that prospectors with competitive advantages will use relatively more shortterm debt for investment expenditure. Moreover, it was found out that when the company is privately owned with less free cash flow and better internal control quality, the negative effect of a business strategy on maturity mismatched investment will be significantly strengthened. These empirical results enrich the understanding of the relationship between a business strategy and maturity mismatched investment.

This research makes the following contributions. First, this paper enriches the relevant literature in the cross-field of business strategy and financial strategy. This paper finds that a business strategy has a significant impact on corporate maturity mismatched investment decisions. Second, this research considers the business strategy to represent a clear path for companies to achieve a competitive advantage. This research takes whether a company already has a competitive advantage into consideration, showing that the condition of competitive advantage has an impact on the relationship between the business strategy and financial behavior. Third, this paper is based on corporate financial data to measure corporate maturity mismatched investment behavior (Zhong et al., 2016). It finds that business strategy is a vital influence factor of corporate maturity mismatched investment decisions. Fourth, this research suggests that there is a tradeoff between an aggressive business strategy and maturity mismatched investment. This finding can help companies better engage in effective risk management and governance to achieve a competitive advantage (Eccles et al., 2014; Rezaee, 2017).

The shortcomings of this paper are related to the limitation of data sources as well as the fact that the business strategy and competitive advantage measurement method may be affected by some noise, especially that the values of competitive advantage are affected by the information authenticity. The competitive advantage condition may be overvalued when managers are overconfident about the situation of a corporation. Moreover, some samples may not be effectively identified due to language ambiguity. Results from studies like ours might be more persuasive if the future research determines measurements of business strategy and competitive advantage that express greater objectivity.

\section{References}

1. Ayyagari, M., Demirgüç-Kunt, A., \& Maksimovic, V. (2010). Formal versus informal finance: Evidence from China. The Review of Financial Studies, 23 (8), 3048-3097. https://doi. org/10.1093/rfs/hhq030 
2. Bentley, K. A., Omer, T. C., \& Sharp, N. Y. (2013). Business strategy, financial reporting irregularities, and audit effort. Contemporary Accounting Research, 30 (2), 780-817. https://doi. org/10.1111/j.1911-3846.2012.01174.x

3. Brown, J. R., Martinsson, G., \& Petersen, B. C. (2013). Law, stock markets, and innovation. Journal of Finance, 68 (4), 1517-1549. https://doi.org/10.1111/jofi.12040

4. Chandler, A. D. (1990). Strategy and structure: Chapters in the history of the industrial enterprise. Cambridge: MIT Press.

5. Chen, G. Z., \& Keung, E. C. (2019). The impact of business strategy on insider trading profitability. Pacific-Basin Finance Journal, 55 (3), 270-282. https://doi.org/10.1016/j. pacfin.2019.04.007

6. Chen, Y., Zhang, B., \& Zhai, R. (2016). Impact of debt structure of state-owned enterprises on innovation: An empirical test of abuse of debt financing. Science Research Management, 37 (4), 16-26. https://doi.org/10.19571/j.cnki.1000-2995.2016.04.003

7. Chiao, C. (2002). Relationship between debt, R\&D and physical investment, evidence from US firm-level data. Applied financial economics, 12 (2), 105-121. https://doi. org/10.1080/09603100110102709

8. Clarkson, P. M., Fang, X., Li, Y., \& Richardson, G. (2013). The relevance of environmental disclosures: Are such disclosures incrementally informative? Journal of Accounting and Public Policy, 32 (5), 410-431. https://doi.org/10.1016/j.jaccpubpol.2013.06.008

9. Cowling, M., Ughetto, E., \& Lee, N. (2018). The innovation debt penalty: Cost of debt, loan default, and the effects of a public loan guarantee on high-tech firms. Technological Forecasting and Social Change, 127 (2), 166-176. https://doi.org/10.1016/j.techfore.2017.06.016

10. Custódio, C., Ferreira, M. A., \& Laureano, L. (2013). Why are US firms using more short-term debt? Journal of Financial Economics, 108 (1), 182-212. https://doi.org/10.1016/j. jfineco.2012.10.009

11. Ding, F., \& Chen, R. (2020). Corporate Strategy Aggressiveness, Analysts'Earnings Forecasts and Information Uncertainty. Journal of Shanxi University of Finance and Economics, 42 (2), 72-86. https://doi.org/10.13781/j.cnki.1007-9556.2020.02.006

12. Ding, Y., \& Hu, X. (2007). Internal Control, Risk Control and Risk Management Based on Organizational Goals of Conceptual Explanation and Ideological Evolution. Accounting Research, 28 (12), 51-54. https://doi.org/10.3969/j.issn.1003-2886.2007.12.007

13. Dvorský, J., Petráková, Z., Khan, K. A., Formánek, I., \& Mikoláš, Z. (2020). Selected aspects of strategic management in the service sector. Journal of Tourism and Services, 11 (20), 109-123. https://doi.org/10.29036/jots.v11i20.146

14. Eccles, R. G., Ioannou, I., \& Serafeim, G. (2014). The impact of corporate sustainability on organizational processes and performance. Management Science, 60 (11), 2835-2857. https://doi. org $/ 10.1287 / \mathrm{mnsc} .2014 .1984$

15. Filipová, V., Drozen, F., \& Kubáňková, M. (2016). Product Inovation and Public Support-Case Study of SME in the Tourist Industry. Journal of Tourism and Services, 7 (12), 7-19. https://jots. cz/public/site/images/kljucnikov/Full_Issue_12.pdf 
16. Gao, Y., \& Liu, M. (2012). Research on Equity Characteristics of Ultimate Controller and Corporation's Investment and Financing Strategy-Empirical Evidence from Listed Chinese Manufacturing Companies. China Industrial Economics, 26 (7), 96-108. https://doi. org/10.19581/j.cnki.ciejournal.2012.07.008

17. Hennessy, C. A. (2004). Tobin's Q, debt overhang, and investment. Journal of Finance, 59 (4), 1717-1742. https://doi.org/10.1111/j.1540-6261.2004.00677.x

18. Huang, R., Tan, K. J. K., \& Faff, R. W. (2016). CEO overconfidence and corporate debt maturity. Journal of Corporate Finance, 36 (1), 93-110. https://doi.org/10.1016/j. jcorpfin.2015.10.009

19. Jensen, M. C., \& Meckling, W. H. (1976). Theory of the firm: Managerial behavior, agency costs and ownership structure. Journal of Financial Economics, 3 (4), 305-360. https://doi. org/10.1016/0304-405X(76)90026-X

20. Kahl, M., Shivdasani, A., \& Wang, Y. (2015). Short-term debt as bridge financing: Evidence from the commercial paper market. Journal of Finance, 70 (1), 211-255. https://doi.org/10.1111/ jofi.12216

21. Kong, D., Yang, X., Liu, C., \& Yang, W. (2020). Business strategy and firm efforts on environmental protection: Evidence from China. Business strategy and the Environment, 29 (2), 445-464. https://doi.org/10.1002/bse.2376

22. Kowalski, A. M. (2020). Towards an Asian Model of Clusters and Cluster Policy: The Super Cluster Strategy. Journal of Competitiveness, 12 (4), 74-90. https://doi.org/10.7441/joc.2020.04.05

23. Lim, E. K., Chalmers, K., \& Hanlon, D. (2018). The influence of business strategy on annual report readability. Journal of Accounting and Public Policy, 37 (1), 65-81. https://doi.org/10.1016/j. jaccpubpol.2018.01.003

24. Liu, C., \& Kong, D. (2020). Business strategy and sustainable development: Evidence from China. Business strategy and the Environment, 30 (1), 657-670. https://doi.org/10.1002/bse.2645

25. Liu, H. (2016). Does Business Strategy Impact a Firm's Earnings Property? An Investigation from the Perspective of Accounting Conservatism. Nankai Business Review, 19 (4), 111-121.

26. Liu, L., Liu, Y., \& Huang, Y. (2004). Empirical Evidence on the Proportion of State-owned Shares, the Choice of Managers and the Relationship Between Redundant Employees and the Governance Failure of State-owned Companies. Management World, 20 (6), 97-105. https://doi. org/10.19744/j.cnki.11-1235/f.2004.06.011

27. Long, Y., \& Chang, Q. (2008). A Study on the Relationships among Types of Innovation, Financing Choice and Market Strategy in Young High-Tech Firm. Science of Science and Management, 29 (1), 70-74.

28. Meng, Q., Li, X., \& Cai, X. (2018). Does Corporate Strategy Influence Corporate Frauds? Nankai Business Review, 21 (3), 116-129.

29. Merkl-Davies, D. M., \& Brennan, N. M. (2007). Discretionary disclosure strategies incorporate narratives: incremental information or impression management? Journal of accounting literature, 27 (1), 116-196. https://ssrn.com/abstract=1089447 
30. Miles, R. E., Snow, C. C., Meyer, A. D., \& Coleman Jr, H. J. (1978). Organizational strategy, structure, and process. Academy of management review, 3 (3), 546-562. https://doi.org/10.5465/ amr.1978.4305755

31. Putintica, A., \& Bonaci, C. G. (2013). Does cash flow affect investment? Evidence from the Romanian capital market. International Journal of Entrepreneurial Knowledge, 1 (1), 53-60. https://doi. org/10.15759/ijek/2013/v1i1/53757

32. Rehman, O. U. (2017). Firms' Aggressiveness and Respective Performance: An Empirical Study under Pakistani Scenery. International Journal of Entrepreneurial Knowledge, 5 (1), 5-19. https://doi. org/10.1515/ijek-2017-0001

33. Rezaee, Z. (2017). Corporate sustainability: Theoretical and integrated strategic imperative and pragmatic approach. Journal of Business Inquiry, 16 (1), 60-87. https://journals.uvu.edu/index.php/ jbi/article/view/77

34. Richardson, S. (2006). Over-investment of free cash flow. Review of accounting studies, 11 (2), 159-189. https://doi.org/10.1007/s11142-006-9012-1

35. Ruzekova, V., Kittova, Z., \& Steinhauser, D. (2020). Export Performance as a Measurement of Competitiveness. Journal of Competitiveness, 12 (1), 145-160. https://doi.org/10.7441/joc.2020.01.09

36. Sheng, Y., Huang, Z., Liu, C., \& Yang, Z. (2019). How does business strategy affect wage premium? Evidence from China. Economic Modelling, 83 (12), 31-41. https://doi.org/10.1016/j. econmod.2019.09.042

37. Sorge, M., Zhang, C., \& Koufopoulos, K. (2017). Short-term corporate debt around the world. Journal of Money, Credit and Banking, 49 (5), 997-1029. https://doi.org/10.1111/jmcb.12403

38. Sun, J., Wang, B., Cao, F., \& Liu, X. (2016). Does corporate strategy affect earnings management? Management World, 32 (3), 160-169. https://doi.org/10.19744/j.cnki.111235/f.2016.03.013

39. Wang, B., Hou, C., \& Sun, J. (2018). The Impact of Business Strategy on Corporate Performances. China Soft Science, 33 (1), 127-137. https://doi.org/10.3969/j.issn.10029753.2018.01.012

40. Wang, H., Gao, P., \& Zhang, X. (2019). Does Business Strategy Affect Excess Perquisites? Accounting Research, 40 (3), 40-46.

41. Wang, H., Zhang, X., \& Gao, S. (2016). Does Corporate Strategy Influence Overinvestment. Nankai Business Review, 19 (4), 87-110.

42. Wang, J. (2011). Comparison on R\&D output elasticity about government and enterprise Journal of Quantitative \& Technical Economics, 28 (6), 94-147. https://doi.org/10.13653/j.cnki. jqte.2011.06.009

43. Wu, H., Mo, S., \& Meng, Q. (2018). Is the corporate strategy responsible for the CEO-employee pay gap? Journal of Management Sciences in China, 21 (9), 110-122. https://doi.org/10.3969/j. issn.1007-9807.2018.09.008

44. Wu, L. (2010). Applicability of the resource-based and dynamic-capability views under environmental volatility. Journal of Business Research, 63 (1), 27-31. https://doi.org/10.1016/j. jbusres.2009.01.007 
45. Xia, G., \& Lu, G. (2012). Capital market, financial constraints and high-tech enterprises' R\&D expenditure: evidence from China listed firms dynamic panel data model with GMM estimation. Studies in Science of Science, 30 (9), 1370-1377. https://doi.org/10.16192/j.cnki.10032053.2012.09.012

46. Xue, S., Xiao, Z., \& Pan, M. (2010). Does the management discussion and analysis provide useful information? Empirical exploration based on loss-making listed companies. Management World, 26 (5), 130-140. https://doi.org/10.19744/j.cnki.11-1235/f.2010.05.014

47. Yu, F., Zhang, M., Jiang, F., \& Ren, M. (2008). Does Corporate Governance Influence Firm's Financial Risk? Accounting Research, 29 (10), 52-59.

48. Zhong, K., Cheng, X., \& Zhang, W. (2016). The Moderate Adjustment of Monetary Policy and the Phenomenon of Corporate Long-term Investment with Short-term Financing. Management World, 32 (3), 87-98. https://doi.org/10.19744/j.cnki.11-1235/f.2016.03.008

\section{Contact information}

Can Wang, Ph. D. Student

Renmin University of China

Business School

Department of Finance

China

E-mail:wangcanruc@ruc.edu.cn

Ing. Tomas Brabenec, Ph.D., LL.M.

University of Economics, Prague

Faculty of Finance and Accounting

Department of Corporate Finance

Czech Republic

E-mail:tomas.brabenec@vse.cz.

ORCID: 0000-0001-6348-2252

Lecturer. Peng Gao, Ph.D. (Corresponding author)

Chongqing University of Technology

Accounting School

Department of Accounting

China

E-mail:gaopeng@cqut.edu.cn

Ziyu Tang, Ph. D. Student

University of Glasgow

Adam Smith Business School

College of Social Sciences

China

E-mail:Ziyu.Tang@glasgow.ac.uk 